\title{
Traceability and Tracking Systems of Halal Food Using Blockchain Technology to Improve Food Industry Competitiveness
}

\author{
Devi Urianty Miftahul Rohmah ${ }^{1}$, Shinta Maharani ${ }^{2}$, Muhammad Nur Kholis ${ }^{3}$, Saiya Umma \\ Taqwa $^{4}$, Haris Setyaningrum ${ }^{5}$ \\ \{deviurianty@unida.gontor.ac.id ${ }^{1}$, shintamaharani@unida.gontor.ac.id², \\ saiyyaummattaqwa@unida.gontor.ac.id ${ }^{4}$,mnurkholis@unida.gontor.ac.id ${ }^{3}$, \\ haris.setyaningrum@unida.gontor.ac.id $\left.{ }^{5}\right\}$ \\ University of Darussalam Gontor, Jl. Raya Siman Km.06 Siman, Ponorogor ${ }^{12345}$
}

\begin{abstract}
Traceability and tracking systems are essential for the halal food industry. The halal food concept is not just limited to food quality and food safety but also includes sources, process control, packaging, storage, and delivery to the end consumers. Consumers not only concerns on food ingredients whether halal or not but also want to know about all the activities involved in the halal food supply chain. The halal food industry can take advantage of digital technology such as blockchain technology to improve halal food industry competitiveness. The purposes of this paper are to review the traceability and tracking system of the halal food today and the use of blockchain technology for halal food traceability and tracking systems. This study proposes the conceptual framework of halal food traceability and tracking system using blockchain technology and discusses its influence on food industry competitiveness.
\end{abstract}

Keywords: blockchain, halal food, traceability, tracking.

\section{Introduction}

Today, food safety is a global concern for the number of food safety scandals that can harm consumers. Healthy and hygiene food is a consideration for consumers to choose a food product. Halal food should be acceptable according to Sharia law, good quality, wholesome and safe.

Halal food is an obligation for Muslims to consume it and has become a trend among nonMuslims. It is because halal food has a higher level of food safety than non-halal food. Halal industry has become one of the fastest growing businesses in the global market and has become the latest trend in the world market [1]. It makes the halal food industry more developed and acceptable by non-Muslim consumers who consider halal food as safe, sanitary, quality and wholesome products.

According to the Shariah law, halal food must fulfil the following conditions: (a) does not contain any nonHalal parts or products of haram animals or products or animals that is not slaughtered in the name of Allah and Shariah methods; (b) does not contain any ingredients that are considered Najis (unclean); (c) safe and not harmful; (d) not prepared, processed or manufactured using tools or equipment that are contaminated or used together with non-halal or Najis; (e) ingredients or byproducts does not contain any human parts; and (f) during the process 
of manufacturing, preparation, packaging, storage or distribution, product must be physically separated between halal and haram products [2].

Consumers who will choose halal food will have doubts if there is lack of transparency of information about the origin and how the product is processed. Besides, during the distribution process to consumers, halal food contamination with illegal products, the non-compliance to halal slaughtering and ill-intentions. Halal logo or certification on the product packaging is presented to inform the consumers about the compliance of food products to the halal guidelines and Sharia law principles. However, another problem is that there are still fake logos or certificates in product packaging [3].

Supply chain actors are the primary key in maintaining and guaranteeing the halalness of a product. Cooperation between different actors must be maintained to ensure the trustworthiness of halal food integrity. A secure platform based on exchanging information, mutuality, and transparency entails mutual benefits across the whole halal supply chain.

Traceability and tracking systems can be used to track information about the product, whether the product is halal, who is the supply chain actors, and the production process. Food traceability is the ability to trace food and its ingredients along with the stages of the supply chain which includes product manufacturing, processing and distributing [4]. The primary characteristics of traceability systems are as follows [5]: (a) identification of units/batches of all ingredients and products; (b) registration of information on when and where units/batches are moved or transformed; and (c) a system linking these data and transferring all relevant traceability information with the product to the next stage or processing step.

The existing tracking system is to manually record the product information, stored in a particular database, and visually accessible to customers. But there are weaknesses or problems from the model scheme; the first is that the data is recorded by human beings and it is challenging to guarantee authenticity, and the information is stored in a centralized data centre. The traceability system using the Internet of Things (IoT) and blockchain can effectively realize the product traceability requirements. The IoT technology is more reliable and realistic than the manual recording and blockchain technology is more credible than centralizing the database. It will also be able to effectively reduce operating costs and improve economic efficiency [6].

Transparency of halal supply chain is needed to ensure trust and authenticity of halal food. The weakness that can affect adoptive ability halal traceability and tracking systems includes the lack of knowledge about halal markets, halal technology and the proper use of halal inputs [7]. Therefore we need a system and technology that can guarantee traceability and tracking systems transparently, especially for halal food. 


\section{Literature Review}

\subsection{Traceability and tracking systems on the halal food industry}

Firms are having three primary objectives in developing, implementing, and maintaining traceability systems: to improve supply management; to facilitate traceback for food safety and quality, and to differentiate and market foods with undetectable quality attributes [8]. Traceability systems are a tool to help manufacturers manage the flow of inputs and improve efficiency, food safety, product quality, and product differentiation.

Halal supply chain management is a process-oriented approach, to manage the flow of material, information and capital; through strategic coordination and collaboration of stakeholders, to create value to improve the performance of the supply chain, which is extended from farm to fork [9]. Traceability and tracking systems on halal food industries can be achieved well if the halal supply chain management runs well too.

\subsection{Blockchain technology}

Blockchain can be defined as a distributed ledger technology that can record transactions between parties securely and permanently. By 'sharing' databases between multiple parties, blockchain permanently removes the need for intermediaries who were previously required to act as trusted third parties to verify, record and coordinate transactions [10]. Blockchain puts data stored in different blocks in a peer-to-peer network where non-trusting nodes can interact with each other without a trusted intermediary, and they supervise mutually. Any data change needs consentient agreement from other blocks. Thus, blockchain is also be known as a Trust Machine [11].

The combination of the distributed ledger technology with smart contracts between supply chain actors that ensure halal has the potential to create high-performance halal supply chain networks [12]. Many projects are underway using blockchain technology to improve supply chain transparency and monitor sources. The data becomes permanent and easily shared, giving supply chain actors more comprehensive track-and-trace capabilities than ever before [10]. The adoption of blockchain offers increased transparency, greater sustainability, and scalability, better safety, and security, fair trade and price equality. Smart contracts in blockchain can eliminate costly delays and paper waste [13].

New decentralized traceability system based on the internet of things and blockchain technology was proposed with using HACCP in the food supply chain [14]. The system will deliver real-time information to all supply chain actors on the safety status of food products, enormously reduce the risk of centralized information systems, and bring more secure, distributed, transparent, and collaborative. That system can significantly improve the efficiency and transparency of the food supply chain, which will enhance the food safety and rebuild the consumer's confidence in the food industry.

\subsection{Competitiveness}

Competitiveness is equated to productivity. There are pillars that effect to country competitiveness [15], they are (1) institutions; (2) infrastructure; (3) ICT adoption; (4) macroeconomic stability; (5) health; (6) skills; (7) product market; (8) labour market; (9) financial system; (10) market size; (11) business dynamism; (12) innovation capability. 
One pillar that is related to traceability and tracking systems is pillar 3: ICT adoption, the degree of diffusion of specific information and communication technologies (ICTs). According to [15]s, ICTs reduce transaction costs and information speed and idea exchange, improve efficiency and sparking innovation. As ICTs are general purpose technologies are increasingly embedded in the structure of the economy, they are needed as power and transport infrastructure for all economies.

\section{Research methodology}

This paper is literature research which reviews based on previous research literature related to food traceability and tracking system. This study proposes the conceptual framework of halal food supply chain, the conceptual framework of halal food traceability and tracking system using blockchain technology and discusses its influence on food industry competitiveness.

\section{Result and Discussion}

\subsection{The conceptual framework of halal food supply chain network}

One of the markers that the halal product is the presence of a logo or halal certificate in the product packaging. According to [16], Halal Certification is a process to get the halal certificate through several steps to prove that materials, production process and Halal Assurance System are complying to the standard of LPPOM MUI.

Principles of Halal Assurance System (HAS) are [16]:

1. Maqoshidu Syariah

As its responsibility to the Muslim community, LPPOM MUI introduced HAS as part of the halal certification process in order to guard the implementation of Syariah Islam (Islamic law) which has primary aim to take care of the holiness of religion, mind, soul, family, and properties of human being, in halal matter.

2. Honest

The company has to honestly explain all materials which are used as well as the production process in Manual of HAS and running the daily operation of halal production based on what is stated in Manual of HAS.

3. Trustworthy

LPPOM MUI trust the company to set Manual of HAS based on the real internal conditions of the company

4. Systematic

Halal Assurance System is appropriately documented and systematically in the form of Manual of HAS to make LPPOM MUI easily traces its implementation proofs in the company

5. Socialized 
Implementation of Halal Assurance System is responsibility at all levels from the top level of management to the employees, therefore HAS must be well-socialized in the company

6. Key person involvement

The company involves persons in to keep the implementation of Halal Assurance System.

7. Management Commitment

Implementation of HAS in the company will be more effective if it is fully supported by top management. Management must mention in a written statement their halal commitment in the company's halal policy.

8. Delegating authority

Management delegates authority of process to the internal halal auditor(s).

9. Traceability

Each implementation of halal production is always recorded and able to be traced

10. Absolute

Materials which are used in the halal production process must have an exact status of its halalness. Halal Assurance System does not have criteria of the low, middle or high-risk status of materials halalness.

11. Specific

The system has to identify each material as a specific entity according to the supplier, manufacturer, and country of origin. It means that one code for one specific material.

Besides being concerned about halal products, consumers are also concerned about food safety and food quality. Assurance of quality and safety of food products, halal food supply chain actors must implement Good Agricultural Practices (GAP), Good Manufacturing Practices (GMP), Hazard Analysis and Critical Control Points (HACCP). Thus, traceability can be emphasized on only reacting or responding to breaches in food safety [5]. Therefore, the proposed framework is based on the application of Haram Analysis and Critical Control Points (HrACCP), GAP, GMP, and HACCP.

This paper purpose conceptual framework of halal food supply chain network shown in Fig.1. The proposed conceptual framework shows that halal implementation is not only in manufacturing, but also in the procurement, distribution, and logistics section. Every actor and even the end consumers can check the halalness of food products, which is described by the existence of halal checkpoints and information systems about halal products are open. For information flow, it is two-way, which can be up-track or down-track. Each halal food supply chain actor must carry out its activities by the food safety assurance system and halal assurance system. The conceptual framework not only guarantees that the product is halal but also safe for consumption and guaranteed quality. 


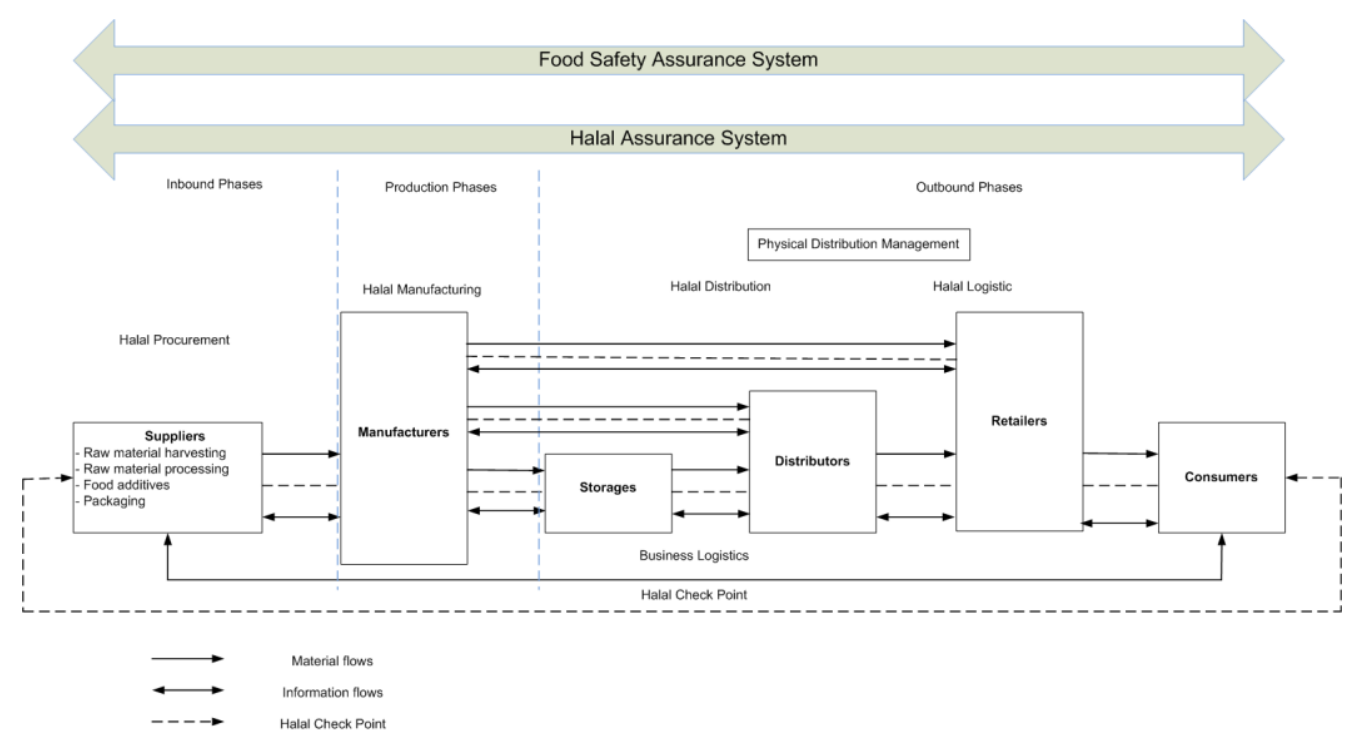

Fig.1. The conceptual framework of halal food supply chain network (adapted from [4] [17][18])

\subsection{The conceptual framework of halal food traceability and tracking system using blockchain technology}

This paper purpose conceptual framework of halal food traceability and tracking system using blockchain technology is shown in Fig.2. The proposed conceptual framework suggests that in addition to supply chain actors in conventional supply chains, there is also a halal certification body and food safety certification body. To achieve ethical halal traceability, cooperation between supply chain actors is needed and a commitment to maintaining consumer trust. Consumers must be able to access information about product halalness, food quality and food safety. With the adoption of blockchain technology, there are smart contracts that must be agreed upon together. So that if there is a party that violates the agreement, it will be detected as a party's unauthorized.

Consumers can scan product code after purchase and enter the page to execute the destruction function to get reward points. If it is not entered into the page that indicates the product has been purchased after the expiration date, it will also be destroyed automatically. Point rewards for consumers can motivate them to feedback, even if not, the validity period can be used to avoid the reuse of the same query code. 


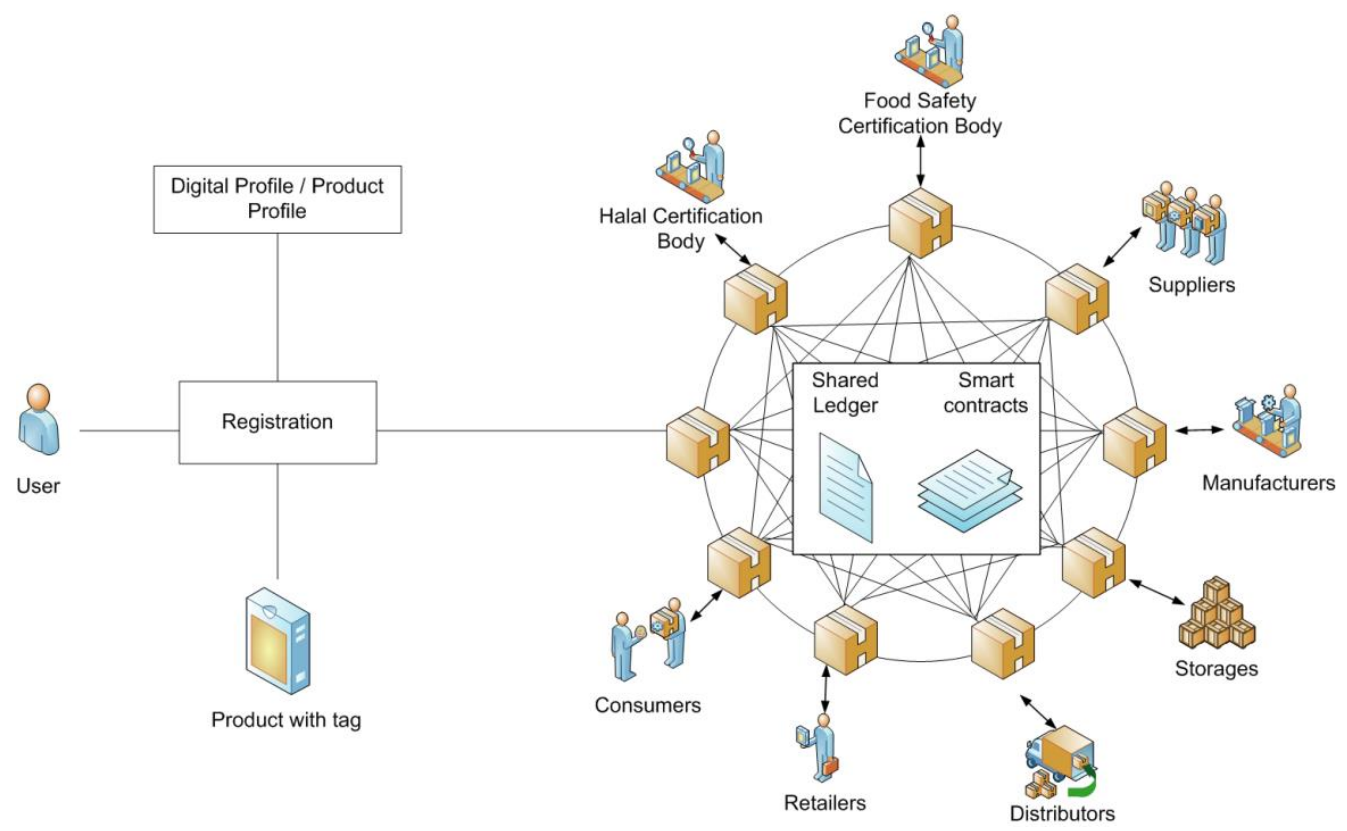

Fig.2. The conceptual framework of halal food traceability and tracking system using blockchain technology (adapted from [3] [12] [14])

\subsection{Competitiveness of the halal food industry}

One pillar that is related to traceability and tracking systems is pillar 3: ICT adoption [15]. By adopting blockchain technology, consumers will increasingly trust food products. Along with increasing consumer confidence, it will increase product sales and will increase productivity as well. Thus it can be said that the use of blockchain technology of traceability and tracking systems can increase the competitiveness of an industry.

\section{Conclusion and Recomendation}

This study proposes the conceptual framework of halal food supply chain and conceptual framework of halal food traceability and tracking system using blockchain technology. The framework is based on food safety, food quality, and halal food by implementing Haram Critical Control Points (HrACCP), Good Agricultural Practices (GAP), Good Manufacturing Practices (GMP), Hazard Analysis and Critical Control Points (HACCP). The use of the blockchain technology of traceability and tracking systems can also increase the competitiveness of the food industry. 
With the addition of IoT technology, it will also increase halal traceability in real time. The need for specific IoT is used to record activities in each supply chain actor. Thus besides transparency, consumers can also track their products in real time. For further research, it can simulate the framework that has been created on existing blockchain platforms.

Acknowledgement. This research was fully funded by the University of Darussalam Gontor, Indonesia. This paper was presented at $1^{\text {th }}$ International Conference on Business, Law and Pedagogy (ICBLP), Sidoarjo, Indonesia.

\section{References}

[1] R. Nurrachmi, “The Global Development of Halal Food Industry: A Survey Halal industry is the latest trend in the world market . With Moslem Halal food market is one of the largest consumer markets in the world as reported by the Stated of The Global Islamic Economy Rep," Tazkia Islam. Financ. Bus. Rev., vol. 11, no. 1, pp. 41-56, 2017.

[2] M. Syazwan, A. Talib, M. Remie, and M. Johan, "Issues in Halal Packaging: A Conceptual Paper Abstract :," CS Canada Int. Bus. Manag., vol. 5, no. 2, pp. 94-98, 2012.

[3] A. Rejeb, "Halal Meat Supply Chain Traceability Based on HACCP , Blockchain and Internet of Things," Acta Tech. Jaurinensis, vol. 11, no. 4, pp. 218-247, 2018.

[4] F. Mohammadian and B. Hajipour, "Halal Cosmetics Supply Chain - A Conceptual Model,” Int. J. Supply Chain Manag., vol. 5, no. 1, pp. 33-43, 2015.

[5] R. Banerjee and K. Ramful, "TRACEABILITY IN FOOD AND AGRICULTURAL PRODUCTS.” International Trade Center, Switzerland, 2015.

[6] W. Hong, Y. Cai, Z. Yu, and X. Yu, "No Title," in Proceedings of 2018 1st IEEE International Conference on Hot Information-Centric Networking (HotICN 2018), 2018, no. HotICN, pp. 254-255.

[7] S. Zailani, Z. Arifin, N. A. Wahid, R. Othman, and Y. Fernando, "Halal Traceability and Halal Tracking Systems in Strengthening Halal Food Supply Chain for Food Industry in Malaysia (A Review)," J. Food Technol., vol. 8, no. 3, pp. 74-81, 2010.

[8] E. Golan, B. Krissoff, F. Kuchler, L. Calvin, K. Nelson, and G. Price, "Traceability in the U . S . Food Supply: Economic Theory and Industry Studies Library Cataloging Record :," Washington, 2004.

[9] M. I. Khan, A. Haleem, and S. Khan, "Defining Halal Supply Chain Management," Supply Chain Forum An Int. J., vol. 19, no. 2, pp. 122-131, Apr. 2018.

[10] M. Heutger and M. Kückelhaus, Blockchain in logistics. Troisdorf: DHL Customer Solutions \& Innovation, 2018.

[11] I. Lin, H. Shih, J. Liu, and Y. Jie, "Food traceability system using blockchain 1," in Proceedings of 79th IASTEM International Conference, 2017, no. October, pp. 59-64.

[12] M. Tieman and M. R. Darun, "Leveraging Blockchain Technology for Halal Supply Chains," Islam Civilisational Renew., vol. 8, no. 4, pp. 547-550, 2018.

[13] V. Thiruchelvam, A. S. Mughisha, M. Shahpasand, and M. Bamiah, "Blockchainbased Technology in the Coffee Supply Chain Trade: Case of Burundi Coffee," J. Telecommun. Electron. Comput. Eng., vol. 10, no. 3, pp. 121-125, 2018.

[14] F. Tian, "A Supply Chain Traceability System for Food Safety Based on HACCP , Blockchain \& Internet of Things," Vienna University of Economics and Business, 2012.

[15] K. Schwab, “The Global Competitiveness Report," Geneva, 2018.

[16] I. C. of Ulama, "Decree Of Assessment Institute For Foods, Drugs, And Cosmetics 
Indonesian Council Of Ulama On Product Name And Product Shape Provision.” LPPOM MUI, Jakarta, 2014.

[17] R. Z. Rasi, N. R. Masrom, S. S. Omar, M. F. Ahmad, and R. Sham, "Withdrawn article: Designing Halal Supply Chain: Malaysia's Halal Industry Scenarios," MATEC Web Conf., vol. 135, 2017.

[18] J. Zhang and T. Bhatt, A Guidance Document on the Best Practices in Food Traceability, vol. 13. 2014. 